\title{
GENETIC STRUCTURATION OF SITOPHILUS ZEAMAIS SUBSERVIENT TO MILLET ACCORDING TO AGROECOLOGICAL ZONES OF SENEGAL (WEST AFRICA)
}

\author{
Ngagne Demba SARR \\ ${ }^{I}$ Student, Faculty of Sciences and Technology, Department of Animal Biology, University cheikh Anta DIOP,
}

\section{Toffène DIOME ${ }^{2}$}

${ }^{2}$ Assistant Professor, Faculty of Sciences and Technology, Department of Animal Biology, University cheikh Anta DIOP.

\author{
Cheikh THIAW ${ }^{3}$ \\ ${ }^{3}$ University of sine saloum ELHADJ IBRAHIMA NIASS sing-sing, BP 55, Kaolack, Senegal
}

Mbacké SEMBENE ${ }^{4}$

${ }^{4}$ Professor, Faculty of Sciences and Technology, Department of Animal Biology, University cheikh Anta DIOP, BIOPASS Laboratory UMR 022 IRD-CBGP

DOI: https://doi.org/10.36713/epra3756

\section{SUMMARY}

In Senegal, millet is the most exploited cereal and the second most one consumed after rice. It is cultivated in most agroecological zones whose more or less arid climatic characteristics favor the development of several insect pests, among which Sitophilus Zeamais, a beetle of the Curculionidae. This insect causes a lot of losses of millet stocks, mainly in four agro-ecological zones: $N B A^{1}, S B A^{2}, S O H C^{3}$ and $B M C^{4}$.

Our study aims to highlight a possible genetic structuring of Sitophilus Zeamais subservient to millet according to these agroecological zones.

The advantage of the existence of a genetic differentiation between agroecological zones is to be able to detect after the degree of genetic homogeneity of each one of them and consequently their impacts on the survival or the extinction of the insect, because the genetic diversity of populations influences their adaptive potentials.

To achieve this goal, we sampled Sitophilus Zeamais insects subservient to millet in each agroecological zone. 43 individuals were harvested in total.

The exploitation of the sequences of the cytochrome $b$ gene corresponding to these individuals has highlighted a genetic structuration of Sitophilus Zeamais subservient to millet according to the 4 agroecological zones, attested by the values of genetic distance, Fst ones and corroborated by the results of the test. AMOVA.

KEYWORDS : Sitophilus Zeamais, cytochrome b, millet, genetic structuring.

\footnotetext{
${ }^{1}$ Nord Bassin Arachidier

2 Sud Bassin Arachidier

${ }^{3}$ Sénégal Oriental Haute Casamance

${ }^{4}$ Basse Moyenne Casamance
} 


\section{INTRODUCTION}

According to the Direction of Forecasting and Economic Studies (DFES, 2018), millet occupies a substantial place of 891069 tons in the total cereal production of the country, estimated at 2553381 tons. The socio-economic function of millet is as important: This cereal is consumed in Senegal in the form of porridge, of couscous by $28 \%$ of the rural population (RAPI ${ }^{5}$. Millet is also a significant source of income for producers. In a current context of poverty reduction in developing countries such as Senegal, millet whose intrinsic characteristics are compatible with the climatic conditions of the different agroecological zones, can play an important role. However, it is potentially damaged by Sitophilus Zeamais, a Coleopteran beetle of the family Curculionidae, in the agroecological zones of the NBA, SBA, SOHC and BMC, where it is grown massively.

So far, genetic studies on this insect have traced its phylogeny and its geographical distribution in Africa in general. The specific case of Senegal has never been studied in this domain.

The objective that we set ourselves in this article is to verify a possible genetic structuring of the insect according to the agroecological zones.

The interest of highlighting a genetic differentiation of the insect according to the agroecological zones, if it exists, is to be able to evaluate after, the genetic diversity of the populations of the agroecological zones, in other words, the influences of these areas on adaptability of the insect, because genetic homogeneity reduces the adaptive capacity of the individual unlike genetic heterogeneity.
For this, insects of Sitophilus Zeamais subservient to millet were harvested in each agroecological zone. The sequences of the cytochrome $\mathrm{b}$ gene corresponding to these individuals have been exploited by population genetics software (Bioédit, DNAsp, Mega, Harlequin ...), with respect to genetic structuring parameters, related to the aforementioned objective.

Other studies will complete it to apprehend the genetic diversity of each AEZ.

\section{MATERIAL AND METHODS \\ II.1. Sampling \\ II.1.1. Sampling localities}

Sitophilus zeamais individuals were sampled in four agroecological zones (AEZ) of Senegal. The choice given to these areas is justified by their vocation naturally agricultural and by ecological and geographical characteristics which specify each of them. This is the AEZ of the North Peanut Basin (NBA) represented by the only locality of Bambey (14 ${ }^{\circ}$ $42^{\prime} 00^{\prime}$ North / $16^{\circ} 27^{\prime} 00^{\prime \prime W e s t}$ ), from the SBA AEZ at Dionewar $\left(13^{\circ} 52^{\prime} 60\right.$ " North / 16 ${ }^{\circ} 43^{\prime} 60$ " West). Samples were also taken from the SOHC ZEA at Missirah (13 ${ }^{\circ} 41^{\prime} 00$ " North / $16^{\circ} 30^{\prime} 01$ " West) and from the BMC AEZ in The Gambia $\left(13^{\circ} 27^{\prime} 09^{\prime \prime}\right.$ North / $16^{\circ} 34^{\prime} 40^{\prime \prime}$ Ouest)). Figure 1 summarizes the study sites in black.

\footnotetext{
${ }^{5}$ Rural Agricultural Prospective Initiative 


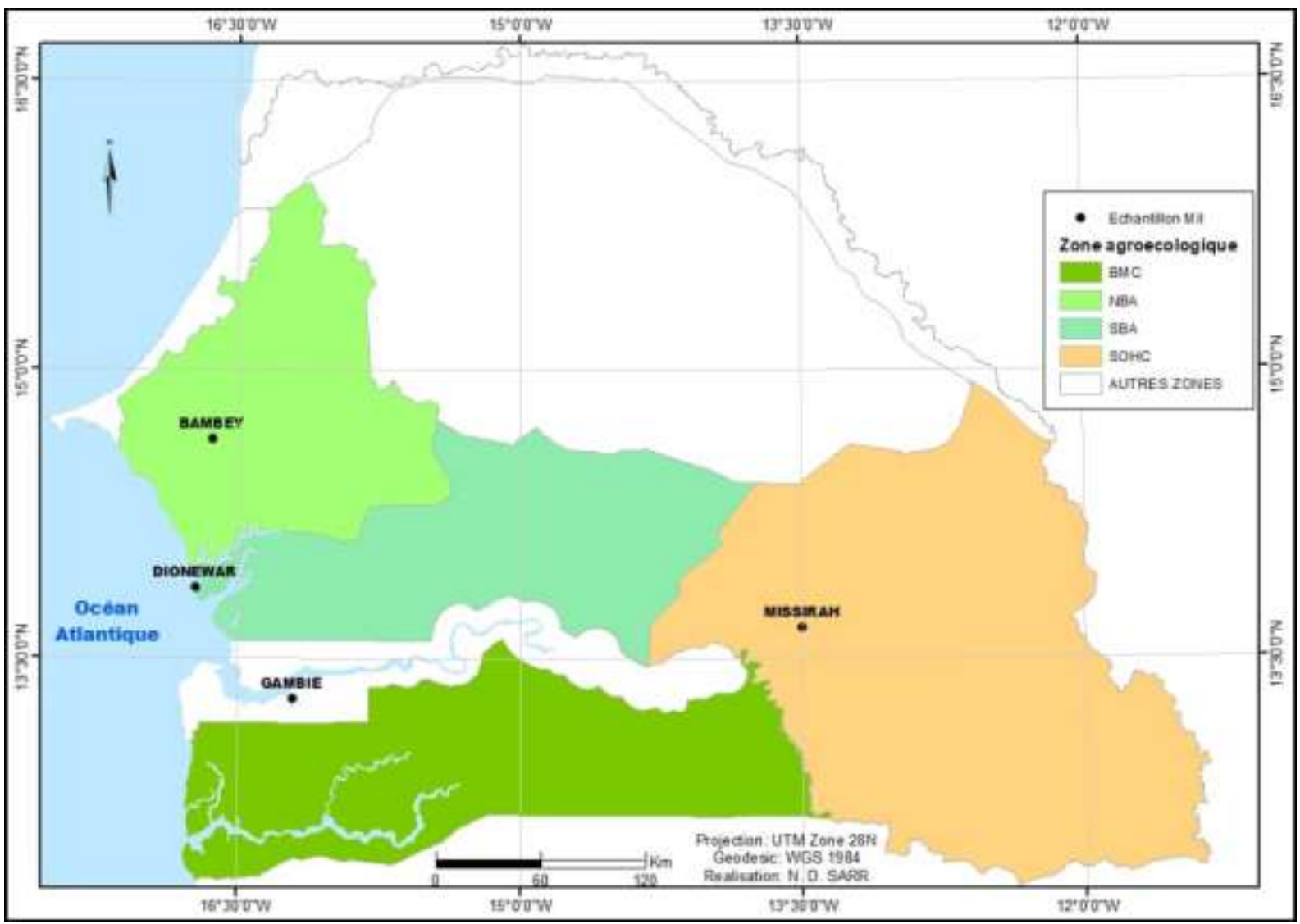

Figure 1 : Sampling locations (in black)

\section{II.1.2. Harvesting individuals}

The collection of infested Millet samples in the different AEZs made it possible to isolate individuals of Sitophilus zeamais for each zone. It has been done in the fields, in storage facilities where grain is highly vulnerable to infestation, but also in marketing places where there is a high chance of encountering infested millet from different AEZs. After isolation, individuals from each AEZ are placed in tubes containing 96\% alcohol.

To code individuals for their host plant, we capitalized the first letter of the insect's genus name and then specified the type of host plant of the individual using the first two letters of the plant (The first letter in upper case and the second in lower case), we have specified the locality of origin (the first letter in capital letters and the second in lowercase), then specify the serial number. Example a Sitophilus zeamais individual who was harvested in Bambey on Mil with the order number 12 is coded as: SMiBa12. if it was on corn from aize, the code would be SMaBa12.

Table 1 summarizes the localities of the AEZs where the harvests took place, the number of individuals sampled for each AEZ, the geographical coordinates of the localities and the codes of the individuals. 


\begin{tabular}{llcc}
\hline NBA & $\mathbf{1 1}$ & & \\
Bambey & 11 & $14^{\circ} 42^{\prime} 00^{\prime \prime} \mathrm{N} / 16^{\circ} 27^{\prime} 00^{\prime \prime} \mathrm{W}$ & SMiBa \\
\hline SBA & $\mathbf{0 9}$ & & \\
Dionewar & 09 & $13^{\circ} 35^{\prime} 00^{\prime \prime} \mathrm{N} / 15^{\circ} 36^{\prime} 00^{\prime \prime} \mathrm{W}$ & SMiDio \\
\hline SOHC & $\mathbf{1 3}$ & & \\
Missirah & 13 & $13^{\circ} 41^{\prime} 00^{\prime \prime} \mathrm{N} / 16^{\circ} 30^{\prime} 01^{\prime \prime} \mathrm{W}$ & SMiMi \\
\hline BMC & $\mathbf{1 0}$ & & \\
Gambie & 10 & $13^{\circ} 03^{\prime} 19^{\prime \prime} \mathrm{N} / 15^{\circ} 38^{\prime} 34^{\prime \prime} \mathrm{W}$ & SMiGa \\
\hline SUM & $\mathbf{4 3}$ & & \\
\hline
\end{tabular}

Table 1 : Sampling locations

\section{II.2. Molecular method of analysis \\ II.2.1. DNA extraction}

The extraction is the DNA release technique of the cell. It includes the individualization of cells (digestion) and the destruction of their plasma and nuclear membranes (lysis).

The digestion of the cells consisted of placing their paws and prothorax into tubes containing ATL buffer and $\mathrm{K}$ proteinases. After incubation, the tubes were centrifuged to separate the supernatant from cell debris.

To destroy the cell membranes, first cell lysis buffer (AL) was added, then some ethanol (96\%) after incubation into the tubes. Then the tubes are transverse in silica membrane columns. Finally, the centrifugation of the tubes allowed to retain the DNA on the siliceous membranes of the columns because negatively charged.

\section{II.2.2. DNA purification}

The tubes DNA was purified by adding 2 buffers AW1 and AW2 in each column. After

Centrifugation of the tubes and precipitation of the DNA at the bottom, the buffers and contaminants are discarded. The columns are then replaced in other tubes in which buffer AE has been added to unhook the DNA. The DNA is thus removed and stored at $-20^{\circ} \mathrm{C}$.

\section{II.2.3. PCR of the mitochondrial gene Cytochrome B}

The PCR of the mitochondrial gene Cyt.B was carried out by two primers $\mathrm{CB} 1$ (5'TATGTACTACCATGAGGACAAATATC-3') and CB2 (ATTACACCTCCTAATTTATTAGGAAT-3'). For each sample (tube), the amplification was made from a total volume of $25 \mu \mathrm{l}$, of which a mixed volume of $23 \mu \mathrm{l}$ and a volume of $2 \mu \mathrm{l}$ of DNA extract. The mixed volume was constituted by: $18.3 \mu$ l of milli water, $2.5 \mu \mathrm{l}$ of $10 \times$ buffer, $1 \mu \mathrm{l}$ of additional $\mathrm{MgCl} 2$, $0.5 \mu$ l of Dntp, $0.25 \mu$ l of each primer and $0.2 \mu$ of Taq polymerase.
The conditions under which the PCR was performed are as follows:

-The DNA strands were first separated with a temperature of $94^{\circ} \mathrm{C}$ for 3 minutes. This first denaturation was followed by 35 denaturation cycles of 1 minute at the same temperature.

-The synthesis of complementary strands (elongation) was made at $72^{\circ} \mathrm{C}$. for 10 minutes. After amplification, the fragments are sent to a South Korean company for sequencing.

\section{II.2.4. Bioinformatics Analyzes}

The sequences were corrected and aligned by the Clustal software implemented in the Bioedit version 7.2.5 program (Hall, 1999).

The genetic structuring of Sitophilus Zeamais according to the agroecological zones was apprehended with respect to genetic differentiation parameters. It's about the genetic distance, the Fst, the Gst and the Amova Test. The genetic distance between Agroecological zones was calculated by the Mega 7 software version 7.0.14 (Tamura et al, 2016), the global Fst and Gst indices by the DNAsp software while the Fst values between populations were calculated by the Arlequin software version 3.5.1.3 (Excoffier and licher, 2010). The indices Fst and Gst are assumed to be similar but they make it possible to check the coherence of the results. The AMOVA test, on the other hand, made it possible to know the part of the variations between agroecological zones in the genetic structuring of the insect.

From the mitochondrial gene Cyt.B, the Network software (Bandel et al., 1999) made it possible to construct the haplotype network according to the maximum parsimony method. The importance of the construction of this network is to check if the possible genetic structuring has appeared there 


\section{RESULTS AND DISCUSSION \\ III.1. Results \\ III.1.1. Spatial structuring of sequences \\ III.1.1.1. Genetic distances}

Genetic distance (GD) within AEZs is variable (Table 2). It is null in SBA and in SOHC, very low in the NBA $(\mathrm{GD}=0.007)$ and relatively low in $\mathrm{BMC}$ $(\mathrm{GD}=0.011)$.

\begin{tabular}{l|l|l}
\hline ZAE & GD & SE \\
\hline NBA & 0,007 & $\mathbf{0 , 0 0 4}$ \\
SBA & 0,000 & $\mathbf{0 , 0 0 0}$ \\
SOHC & 0,000 & $\mathbf{0 , 0 0 0}$ \\
BMC & 0,011 & $\mathbf{0 , 0 0 7}$ \\
\hline
\end{tabular}

Table 2: Genetic distance (in black) within Mil-dependent Sitophilus zeamais populations in different AEZs and standard errors (in blue) calculated from MEGA software for Cyt.B

The genetic distance between agroecological zones is also variable (Table 2). Some AEZs are very divergent. This is the case on the one hand of NBA and $\mathrm{SBA}(\mathrm{GD}=0.030)$ and on the other hand of $\mathrm{BMC}$ and SOHC (GD = 0.02). On the other hand, the DG between other AEZs is relatively small.

\begin{tabular}{l|ccll}
\hline ZAE & NBA & SOHC & BMC & SBA \\
\hline NBA & - & 0,015 & 0,008 & 0,021 \\
SOHC & 0,015 & - & 0,014 & 0,012 \\
BMC & 0,013 & 0,022 & - & 0,012 \\
SBA & 0,030 & 0,012 & 0,016 & - \\
\hline
\end{tabular}

Table 2 : Genetic distance (below the diagonal) obtained by comparing 2 to 2 populations of Mildependent Sitophilus zeamais in AEZs and standard errors (above the diagonal) calculated from the MEGA software for Cyt. B.

\section{III.1.1.2. Genetic differentiation}

The values of Fst between AEZ are very high overall (Table 3). Only the NBA and BMC populations are relatively close. The other AEZs are very genetically distinct.

$\begin{array}{ccccr}\text { ZAE } & \text { NBA } & \text { SOHC } & \text { BMC } & \text { SBA } \\ \text { NBA } & * & & & \\ \text { SOHC } & 0,8105 & * & & \\ \text { BMC } & 0,11292 & 0,84566 & * & \\ \text { SBA } & 0,63341 & 1,00000 & 0,70602 & *\end{array}$

Table 3 : Genetic differentiation values (Fst) between ZAEs calculated from the ARLEQUIN software. All values are significant. 


\section{III.1.1.3. The AMOVA Test}

The very high and significant value of Fst (Fst $=$ $0.77652 \mathrm{PV}=0.000)$, resulting in a percentage variation of $77.65 \%$, indicates that there is a structuration of Sitophilus zeamais subservient to millet according to agroecological zones. (Table 4).

\begin{tabular}{lcclc}
\hline Source of variation & D.f. & $\begin{array}{l}\text { Sum of } \\
\text { Squares }\end{array}$ & $\begin{array}{l}\text { Components of } \\
\text { Variance }\end{array}$ & $\begin{array}{l}\text { Percentage of } \\
\text { variation }\end{array}$ \\
\hline $\begin{array}{l}\text { Between agro-ecological } \\
\text { zones }\end{array}$ & 3 & 80,204 & $2,43706 \mathrm{Va}$ & 77,65 \\
& & & & \\
$\begin{array}{l}\text { Inside the agro-ecological } \\
\text { zones }\end{array}$ & 39 & 27,355 & $0,70140 \mathrm{Vb}$ & 22,35 \\
\hline
\end{tabular}

Table 4 : Molecular Variance Test (AMOVA) between AEZ.

$\mathrm{Va}$ and $\mathrm{FST}=0.77652, \mathrm{pV}=0,0000$

\section{III.1.2. Haplotype network}

The haplotype network (Figure 2) reveals a star structure with two majority haplotypes H2 and H6 representing respectively $51 \%$ and $30 \%$ of the dataset. The majority and ancestral haplotype $\mathrm{H} 2$ is present in all agroecological zones, except that of the low middle Casamance. Haplotypes of BMC (H8 and H7), SOHC
(H6) and NBA (H3) are derived from H2. But the BMC haplotypes are phylogenetically closer to $\mathrm{H} 2$ than the other haplotypes of the other AEZs, insofar as they diverge from it, at most 3 mutational steps, against 7 for the SOHC haplotype and 15 for the SOHC haplotype. NBA.

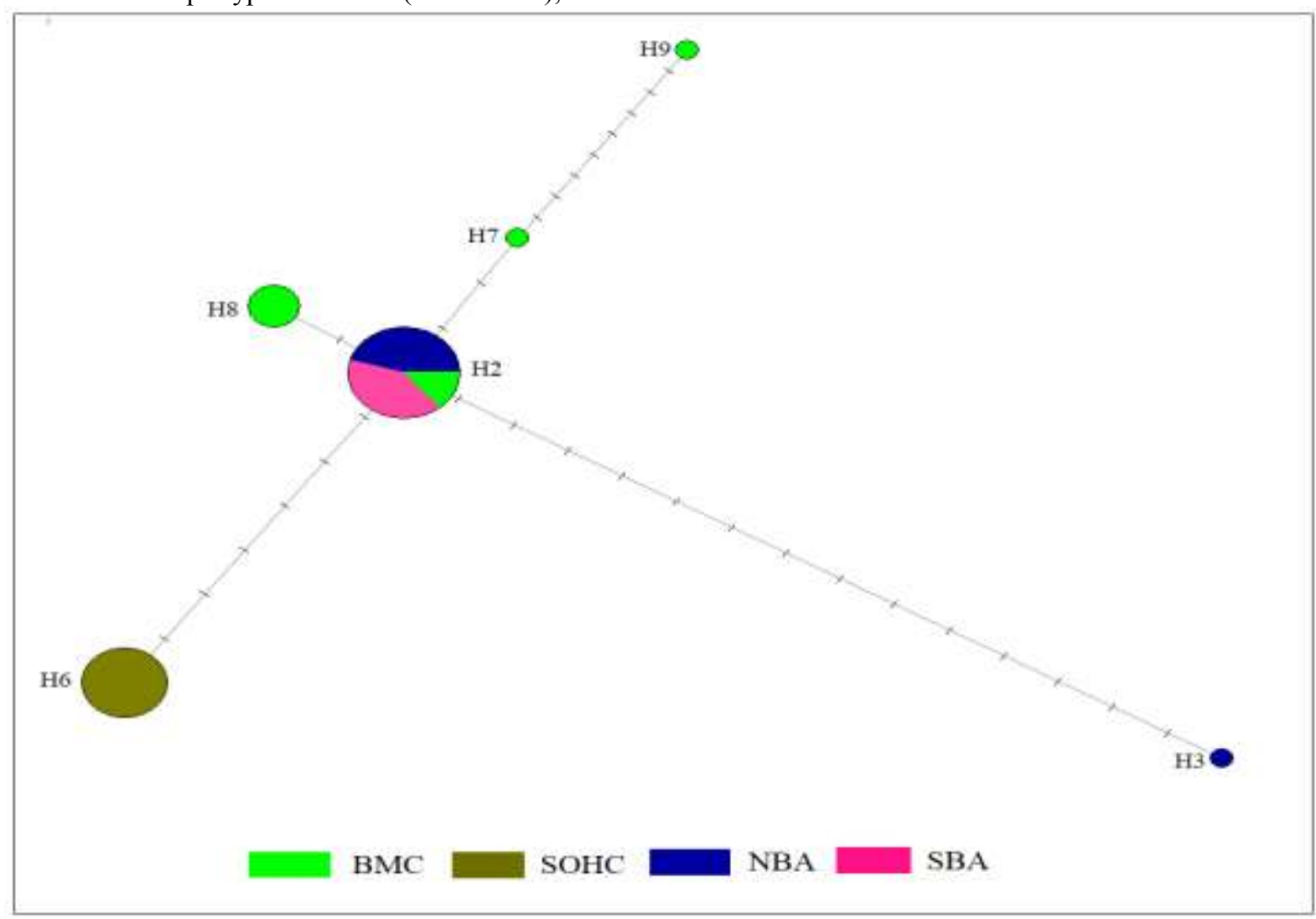

Figure 2: Haplotype network of Sitophilus Zeamais subservient to the host plant, Mil. Each disc corresponds to a haplotype, and their size is proportional to the number of individuals corresponding to the haplotype. The traits correspond to mutational steps between haplotypes. 


\section{III.2. Discussion}

Genetic studies carried out on the geographical distribution of Sitophilus zeamais subservient to maize in West Africa (Ndong et al) and in Senegal (first chapter of my thesis) revealed a genetic distribution of this insect according to agroclimatic or agroecological zones.

In this article, we set ourselves, among other objectives, to verify if the population of Sitophilus zeamais subservient to millet also has the same genetic distribution as that specific to maize.

Data on genetic distance between agroecological zones showed a differential genetic divergence of populations taken in pairs. It is very high on the one hand between the NBA and the SBA and on the other hand between the BMC and the SOHC. But it is relatively high among other AEZs. The values of the fixation index between AEZ cross in the same direction as the genetic distance and confirm the genetic differentiation of the insect, which is finally corroborated by the AMOVA test, with a very high and significant Fst.

But the genetic differentiation of Sitophilus zeamais individuals specific to millet according to the agroecological zones attested by the DG, the Fst, then corroborated by the AMOVA Test is not obvious in the haplotype network. There is a majority haplotype shared between three AEZs out of four studied. Such a fact might not be enough to call into question the genetic structuring of the insect. Because this structuring can be posterior, that is to say, occur after the presence of the shared haplotype in the AEZ. Indeed, the intrinsic and individual climatic characteristics of each zone can be at the origin of the appearance of private haplotypes in each AEZ from the autochthonous haplotype which is the shared haplotype. This explanation is all the more plausible because of all the haplotypes in the dataset, only the haplotype in question is the shared between the AEZs. The other haplotypes are specifically distributed in AEZs.

Genetic structuring is not the result of geographical distance. AEZs are not so far apart to individualize genetically. There are also no physical and especially hydraulic obstacles that separate them, which can limit the gene flow between them.

On the other hand, genetic differentiation between AEZs can be linked to unacceptable characteristics of the insect. Indeed, studies have revealed that intrinsic factors can influence the genetic structuring of certain animals. Norberg et al., (2000) have shown that the long-winged Pteropus livingstonii rescuer species has been genetically patterned on two islands, in contrast to another species of the same genus (Pteropus S. comorensis). who has short wings.

Sitophilus zeamais unlike Sitophilus Oryzae is not a good sailboat (Kranz et al, 1997). Thus, the low mobility of the insect can limit each population in its area and reduce the possibilities of migration between agroecological zones.

\section{CONCLUSION}

According to the study we conducted on the geographical distribution of Sitophilus Zeamais in Senegal, there is a genetic structuring of the insect according to the agroecological zones of the country. It remains to carry out further studies to detect the degree of genetic homogeneity of each zone in order to know if their genetic diversity is likely to influence the adaptability of the insect.

\section{BIBLIOGRAPHIC REFERENCES}

1. Allen $P J$, Amos $W$, Pomeroy $P$, Twiss $S D$. (1995). Microsatellite variation in grey seals (Halichoerus gry-pus) shows evidence of genetic differentiation between two British breeding colonies. Molecular Ecology, 4 (6), 653-62.

2. Almeida $\boldsymbol{F} C$, Giannini $N \boldsymbol{P}$, Simmons $N \boldsymbol{B}$ and Helgen K M. (2014). Each Flying Fox on Its Own Branch: A Phylogenetic Tree for Pteropus and Related Genera (Chiroptera: Pteropodidae). Molecular phylogenetics and evolution, 77C, 83-95.

3. Amsellem L. Risterucci, A.M. \& Benrey B. (2003). Isolation and characterization of Polymorphic microsatellite loci in Lobesia botana Den. \& Schiff. (Lepidoptera: Tortricidae), Molecular Ecology. 5 (4), 53-62.

4. Anonyme: Caractérisation des systèmes de production agricole au Sénégal. P.7-13 Vol. 39 p.

5. Arbogast B S, Kenagy $\boldsymbol{G} \boldsymbol{J}$. (2001). Comparative phylogeography as an integrative approach to historical biogeography. Journal of Biogeography, 28, 819-825.

6. Barallon $\boldsymbol{R}$. 2oos. Species determination by analysis of the cytochrome $b$ gene. Methods in Molecular Biology, 98, 251-260.

7. Barton $\boldsymbol{N} \boldsymbol{H}$. (2001). The role of hybridization in evolution. Molecular Ecology, 10, 551-568.

8. Barton $\boldsymbol{N} \boldsymbol{H}$, Hewitt $\boldsymbol{G} \boldsymbol{M}$. (1985). Analysis of hybrid zones. Annual Review of Ecology and Systematics, 16, 113-148.

9. Berthier K, Galan M, Foltete J.C Charbonnel $\boldsymbol{N} \&$ Cosson JF. (2005). Genetic structure of the cyclic fossorial water vole (Arvicola terrestris): landscape and demographic Influences. Molecular Ecology, 14, 2861-2872.

10. Belkhir K, Borsa P, Chikhi L, Raufaste $N$, Bonhomme F. (1996-2004). GENETIX 4.05, Windows TM software for population genetics. Laboratory Genome, Populations, Interactions, CNRS UMR 50OO, University of Montpellier II, Montpellier (France).

11. Berthier K, Charbonnel N, Galan M, Chaval Y \& Cosson $\boldsymbol{J} \boldsymbol{F}$. (2006). Migration and Recovery of the genetic diversity during the increasing density phase in cyclic vole Populations. Molecular Ecology, 15, 2665-2676.

12. Berthier $K$, Galan M, Foltete $J$ C, Charbonnel $\boldsymbol{N} \&$ Cosson $\boldsymbol{J} \boldsymbol{F}$. (2005). Genetic structure of the cyclic fossorial water vole (Arvicola terrestris): landscape and demographic Influences. Molecular Ecology, 14, 2861-2872.

13. Bezzerides $A$, Bezzerides, $J \&$ Eisner $T$. (2004). Isolation of five polymorphic microsatellite markers in Utethesia ornatrix (Lepidoptera: Artiidae), Molecular Ecology Notes, vol. 4: 566-567*.

14. Berthier K., Galan M., Foltete J.C., Charbonnel N. \& Cosson J.F. (2005). Genetic structure of the cyclic fossorial water flies (Arvicola 
terrestris): landscape and demographic Influences. Journal of Molecular Ecology, 14, 2861-2872.

15. Chala NAFKHA, S. EZZEDDINE, B. CHEMMAM, O. JARDOUI and $K$. FADHLAOUI-ZID: Analysis of the cytochrome $b$ gene of mitochondrial DNA in Octopus octopus VULGARIS (CEPHALOPDA, OCTOPODA) of North and South Tunisian coasts. p.35-36; P.38-40. Vol.41 p.

16. Chan L M, Goodman S, Nowak $M D$, Weisrock $D W$ and Yoder $A$ D. 2011. Increased population sampling confirms low genetic divergence among Pteropus (Chiroptera: Pteropodidae) fruit bats of Madagascar and other western Indian Ocean Islands. PloS Curr, 21, 1-17.

17. Diome T, Ndiaye A, Ndong A, Doumma A, Sanon A, Ketoh GK, Sembene. (2011). Genetic identification of West African ecotypes of the groundnut seed-beetle Caryedon serratus $\mathrm{Ol}$. (Coleoptera, Chrysomelidae). South Asian Journal of Experimental Biology 1 (2):88-93.

18. Doadrio I, Carmona J A. (2004). Phylogenetic relationships and biogeography of the genus Chondrostoma in-ferred from mitochondrial DNA sequences. Molecular Phylogenetics and Evolution, 33, 802-815.

19. Dubut V, Martin J F, Gilles A, Van Houdt J, Chappaz R, Costedoat C. (2009) (sous presse) Isolation and characterization of polymorphic microsatellite loci for the dace complex: Leuciscus (Teleostei: Cyprinidae). Molecular Ecology Resources, doi: $10.1111 / j .1755$-0998.2009. 02594.x

20. Eckenwalder $\boldsymbol{J}$ E. (1998). Hybridization as evolutionary creation. American Journal of Botany, 85 (7), 1043-1045.

21. Emelianov I, Mallet, $\boldsymbol{J} \&$ Baltensweiler $\boldsymbol{W}$. (1995). Genetic differentiation in Zeiraphera Diniana (Lepidoptera: Tortricidae, the larch budmoth): polymorphism, host races or Sibling species? Heredity, 75, 416-424.

22. Fox S, Waycott M, Blair D and Luly J. (2012). Regional Genetic Differentiation in the Spectacled Flying Fox (Pteropus Conspicillatus Gould). In: Haberle S.G. and David B. (eds.). Peopled Landscapes: Archaeological and Biogeographic Approaches to Landscapes. Terra Australis 34, pp 459-472.

23. Isman Abdi b. (2012). Diversity and genetic structuring of the populations of a devastating insect of stocks of millet in Senegal : Tribolium castaneum Herbst (Coleoptera : Tenebrionidae). Memory of master of Genetics of the populations, University Cheikh Anta Diop of Dakar. 29p

24. Klein M, Seitz A. (1994). Geographic differentiation between populations of Rhinocyllus conicus Frölich (Coleoptera : Curculionidae) : concordance of allozyme and morphometric analysis. Zool. J. Linnean Soc., 110:181-191.

25. NDONG A. 2015 : Genetic Characterization of Sitophilus ssp. Maize Zeamais M. Stockpile Destroyer and Manioc esculenta C. cassava mosaic virus eradication trials by in vitro culture. P.33-61. 